\title{
Oral Communicative Activities in the Saudi Third Year Secondary EFL Textbooks
}

\author{
Zaky H. Abu Ellif and Nooreiny Maarof \\ (Universiti Kebangsaan Malaysia, Malaysia) \\ doi:10.7575/aiac.alls.v.1n.1p.7
}

\begin{abstract}
This study aims to examine the oral communicative activities found in the Saudi EFL third year secondary textbooks and to determine the role they play in influencing the learners' oral communication in English. A questionnaire of 52 items based on four domains is utilized to explore the perception of Saudi EFL teachers regarding the oral communicative activities found in the textbooks. The preliminary survey, conducted on a group of Saudi teachers who are using the target textbooks, showed that the textbooks do not have highly communicative activities for fluency development. The participants' rating of the activities, found in the textbooks, was very low. The activities seem to be highly structured and lack free communicative activities. The study shows that the textbooks require much modification. Other types of oral communicative activities should be included to fulfill the goals of developing the Saudi learners' oral fluency in English.
\end{abstract}

\section{Introduction}

Many researchers emphasize the role that textbooks play in the EFL classroom. Ansary et al. (2002) argue that EFL textbooks are always used as the only source of teaching materials in the classroom. According to De Matos (2000), the textbook is still considered as central to teaching-learning process by the majority of teachers in most, if not all, national educational systems. Ansary et al. (2002) also point out that teachers feel more secure when they have ready-made textbooks. In some countries textbooks are not considered the most demanding factor in EFL teaching and learning since other types of material take great participation in shaping the curriculum. The situation in Saudi Arabia is a bit different. Teachers without inhand textbooks are unable to tackle the teaching process and learners as well consider the early days in the school year, while they have a few periods before textbooks are distributed, as waste of time. However, although these textbooks might offer guidance for many teachers, they ignore the individual differences and inhibit teachers' creativity (ibid). The situation 
mentioned above brings out the outstanding role that textbooks play in teaching EFL in Saudi schools. It also drives to ask whether these sets of textbooks fulfill the oral communicative competence among Saudi learners. This question highlights the need to examine the points of strength/weakness within the oral communication activities found in the target textbooks.

\section{Arab learners and Oral communication in English}

Rababah (2003) states that the eventual goal of English language teaching is to develop the learners' communicative competence. This will enable them to communicate successfully in the real world. Successful communication refers to passing on a comprehensible message to the listener. Kharma et al. (1989) state that ESL learners have serious difficulties in learning English pronunciation, even when they are quite perfect in the other language skills (vocabulary, grammar, reading, etc). Alseghayer (2007) states that the Saudi student, by the end of the secondary school, has the minimum level of skills in English language. The student is unable to hold a short dialogue, understand a reading text or write a short essay (ibid). Rababaa (2003) concludes that Arab learners face problems in all the language skills. However, most of their errors in English emerge in oral performance and their choice of communication strategies. Even outstanding Arab learners of English have problems in listening and speaking skills. Kharma et al. (1989) assert that Arab learners, who spend hundreds of hours every school year in learning English, should be able to communicate fluently and efficiently but they show deficiency. They (ibid) also indicate that the learners' attitude towards English language is a mere school subject to pass its test not a means of communication. Rababaa (ibid) echoes Sulaiman's (1983) argument that the major problem faced by Arab students attending universities is that they find it difficult to communicate in English.

\section{Oral communicative activities}

National Center for Family Literacy et al. (2008, p.41) state that communicative activities include any activities that encourage and require a learner to speak with and listen to other learners, as well as with people in the program and community. Brown (2001) adapted Crocker and Chaudron's classifications and came up with 38-item taxonomy of languageteaching techniques under three main categories: a) controlled techniques, b) semi-controlled techniques and c) free techniques. Under each technique he mentioned a group of tasks and activities. Littlewood (1983) referred to two major activity types: a) functional communication activities: ones aimed at developing certain language skills and functional 
aspects of the language, but which involve communication, and (b) social interaction activities, ones which emphasize social and functional aspects of communication, such as conversation and discussion sessions, dialogues and role plays.

Nunan (2000) classifies the types of listening texts into monologue (planned and unplanned) and dialogues (interpersonal and transactional). The interpersonal dialogues are also divided to formal and informal. Regarding speaking types, he adopts Bygate's (1987) taxonomy. Bygate (1987), identifies two main categories of speaking types, routines and negotiations. Routines can focus either on information or interaction. Information routines contain types of information structures which are either expository (e.g. narration, description, instruction, comparison) or evaluative (e.g. explanation, justification, prediction, decision). Interaction routines can be either service such as a job interview or social such as a party. Bygate mentioned another feature of oral interaction for negotiation of meaning or management of the interaction in terms of who is to say what to whom when about what (Nunan, 2000) (See Figure 1). Brown (2001), Savignon et al. (2003) and Littlewood (1983) classified communicative skills, techniques, tasks and activities in general with consideration of the four linguistic skills. However, Murphy (1991) states that the oral communication skills are speaking, listening, and pronunciation. Beale (2002) also refers to speaking, listening and fluency. 

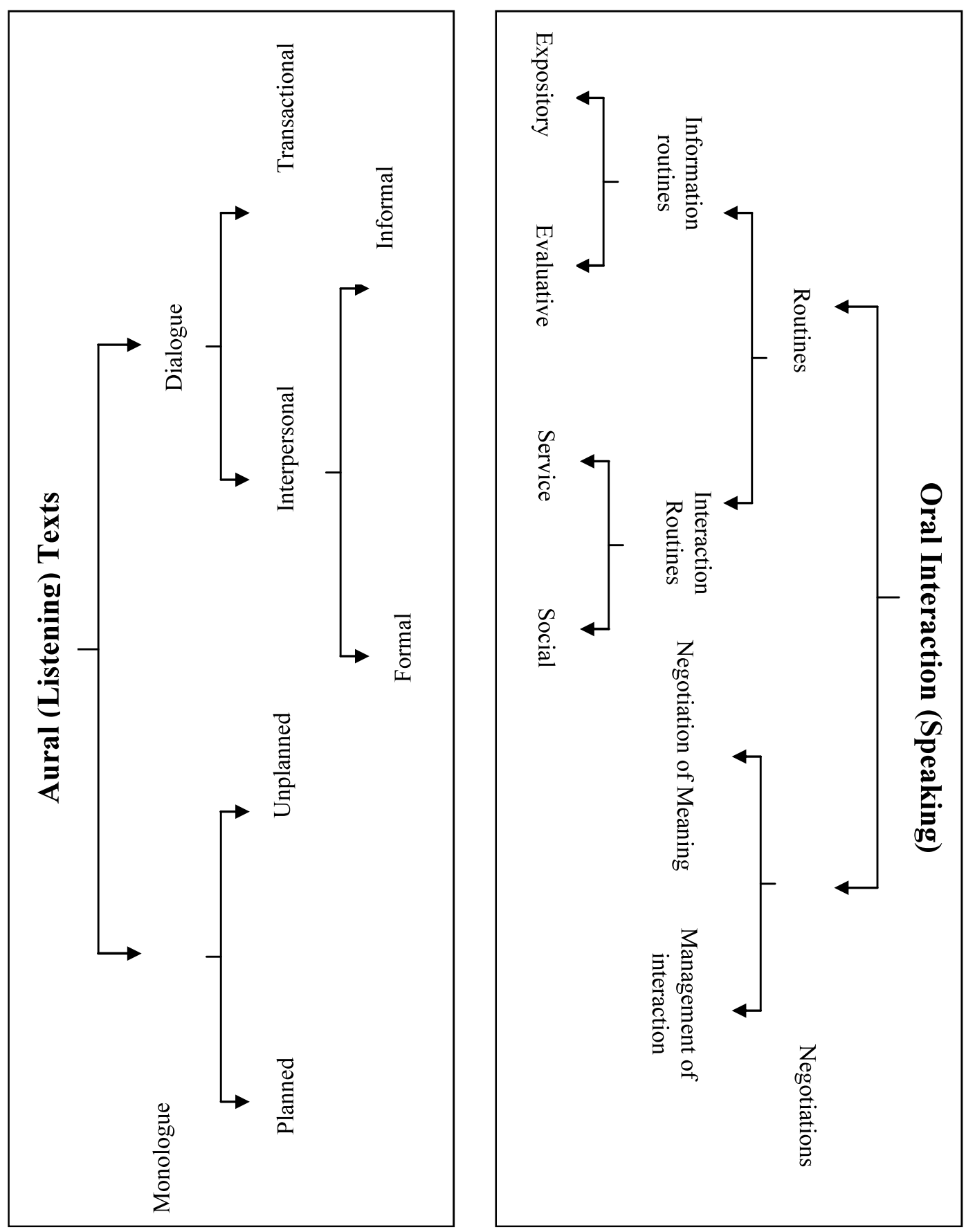

Figure 1: Classification of listening and speaking tasks (Adapted from Nunan, 2000 \& Bygate, 1987)

\section{Instrumentation}

In this study, a 52-item questionnaire is utilized for the collection of data regarding Saudi EFL teachers' perception of oral communicative activities in the EFL textbooks taught to the 
third-grade of public secondary schools in Saudi Arabia. The questionnaire is a relatively popular means of collecting data among students (Nunan, 2002).

\section{Questionnaire}

The domains and items are based on the goals of this study. The questionnaire starts with section (a) which requires the participants to provide some basic information. The next sections $(b-e)$ consist of 52 items based on four domains, which are: (b) communicativeness of the activities found in the Saudi third year secondary EFL textbooks (12 items), (c) effectiveness of the activities found in the Saudi third year secondary EFL textbooks (12 items), (d) types of oral communicative activities in the Saudi third year secondary EFL textbooks (26 items) and finally (e) recommendation to improve the current Saudi third year secondary EFL textbooks. The 5-point Likert type scale was used to allocate numerical values to the responses of domains $\mathrm{B}, \mathrm{C}$ and $\mathrm{D}$. The last domain of the questionnaire is an open-end question where teachers are asked to state their suggestions and recommendations.

\section{Instrument Validity}

A panel of 10 experts from UM, UIAM, UPM, UUM, LIM KOK WING University (Malaysia) and Sana'a University (YEMEN) in the field of teaching EFL / ESL, reviewed the measurement. The researcher followed the experts' recommendations until consensus on the questionnaire has been achieved.

\section{Data collection}

A preliminary study was conducted by administering the questionnaire to a group of teachers thought Saudi English website (www.saudienglish.net). The response rate was about 49 percent with 34 teachers out of 70 responding to the questionnaire via email. Four responses were excluded; three were not complete while the fourth had been answered carelessly. The cronbach's alpha coefficient and Guttman Split-Half Coefficient reliability tests were used to obtain the reliability estimate for the instrument. The results, in Table 1, refer to excellent reliability:

\section{Table 1: Reliability of the questionnaire}

\begin{tabular}{ll}
\hline The coefficient & The value \\
\hline Cronbach's alpha & .921 \\
Guttman Split-Half & .902 \\
\hline
\end{tabular}




\section{Data analysis}

The participants' responses to the questionnaire were transferred to SPSS programme in order to calculate the mean and standard deviation of all items and domains. The means of the three domains are shown in Table 2.

Table 2: The mean of three domains in the questionnaire

\begin{tabular}{llc}
\hline No & \multicolumn{1}{c}{ Domain Title } & Mean \\
\hline B & Communicativeness of the activities found in the Saudi $3^{\text {rd }}$ year secondary EFL textbooks & 1.673 \\
C & $\begin{array}{l}\text { Effectiveness of the activities found in the Saudi } 3^{\text {rd }} \text { year secondary EFL textbooks in } \\
\text { developing oral communicative skills }\end{array}$ & 1.675 \\
D & Types of Oral Communicative activities in the Saudi $3^{\text {rd }}$ year secondary EFL textbooks & 1.626 \\
\hline
\end{tabular}

Table (2) shows how the means of all items are less than 2 on a scale of 5 grades. This shows how all participants' responses fall between strongly disagree or disagree on the three domains. This also reflects how the activities found in the Saudi third year secondary EFL textbooks have low level of oral communicativeness and lack effectiveness in developing oral communicative skills. The mean of domain (D) shows that the effective types of oral communicative activities are hardly found in the target textbooks. For more details, the items of each domain will be discussed separately.

Table 3: The mean and standard deviation of domain (B): Communicativeness of the activities found in the textbooks

\begin{tabular}{lllc}
\hline No & \multicolumn{1}{c}{ Item } & Mean & Std. Deviation \\
\hline B1 & $\begin{array}{l}\text { The third year secondary textbooks give equal emphasis on the four skills (listening, } \\
\text { speaking, reading and writing). }\end{array}$ & 1.73 & 0.785 \\
B2 & $\begin{array}{l}\text { The textbooks incorporate listening activities which help students to communicate } \\
\text { effectively in English. }\end{array}$ & 1.93 & 0.868 \\
B3 & $\begin{array}{l}\text { The activities in the textbooks enable students to communicate orally with each other } \\
\text { in English. }\end{array}$ & 1.87 & 0.973 \\
B4 & $\begin{array}{l}\text { Oral communication activities (listening \& speaking) in the textbooks are sufficient to } \\
\text { develop oral fluency. }\end{array}$ & 1.33 & 0.661 \\
B5 & $\begin{array}{l}\text { The activities in the textbooks help students to speak English fluently. } \\
\text { B6 }\end{array} \quad \begin{array}{l}\text { The activities in the textbooks help students to speak English accurately } \\
\text { (grammatically correct). }\end{array}$ & 1.3 & 0.596 \\
B7 & $\begin{array}{l}\text { The activities in the textbooks help students to speak English properly (suitable } \\
\text { language for each situation). }\end{array}$ & 1.87 & 1.167 \\
B8 & The textbooks include activities that help improve the students' pronunciation. & 1.67 & 0.959 \\
B9 & $\begin{array}{l}\text { The dialogues in the textbooks help students practice free speaking. } \\
\text { B10 }\end{array} \quad \begin{array}{l}\text { The pictures in the textbooks support the speaking skill. } \\
\text { B11 }\end{array} \quad \begin{array}{l}\text { The two Writing textbooks (Term 1 \& 2) contain enough listening and speaking } \\
\text { activities. }\end{array}$ & 1.67 & 0.922 \\
B12 & The themes in the textbooks enable students to communicate orally in English. & 1.33 & 0.802 \\
\hline & Mean B & 1.67 & 1.028
\end{tabular}


Table (3) shows how the means of all items are between 1 and 2 on a scale of 5 grades. This shows how all participants' responses are either strongly disagree or disagree on all the domain items. On the other hand, the standard deviation values are less than one or around one which reflects some consensus among the respondents that the activities in the target textbooks have low communicativeness as it is clear in figure 2 where on $\mathrm{Y}$ axis 1 refers to (strongly disagree) and 5 refers to ( strongly agree).

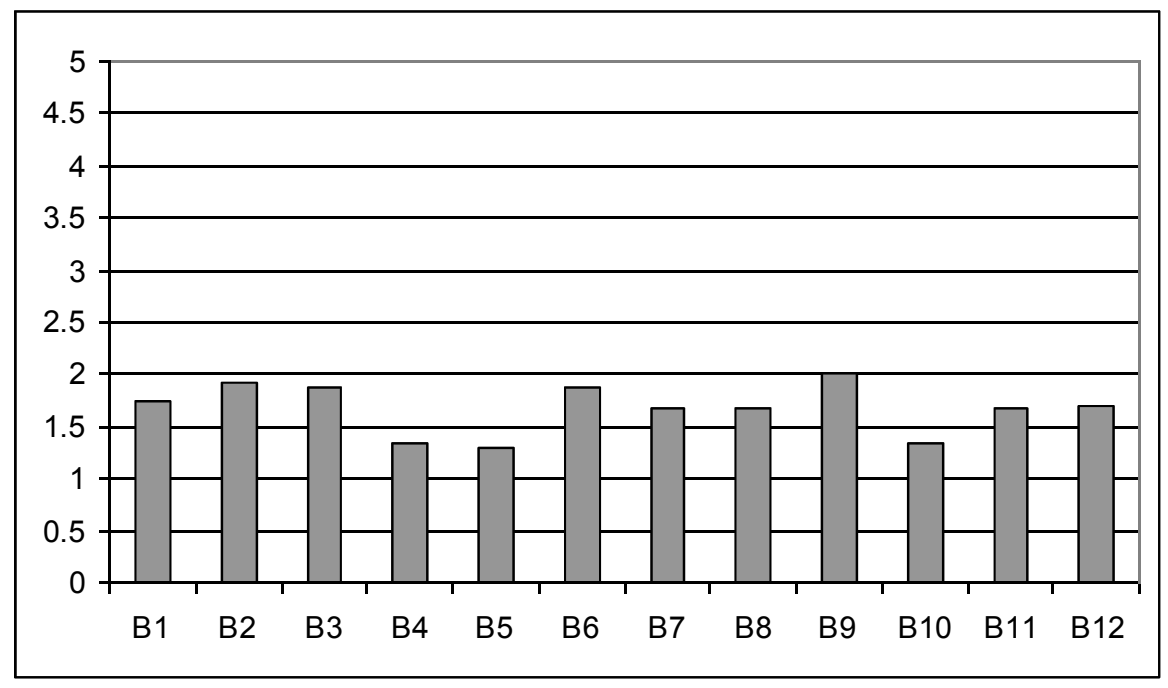

Figure 2: Means of responses for each item in domain $B$

For domain (C) in the questionnaire, (Effectiveness of the activities found in the 3rd year secondary EFL textbooks in developing oral communicative skills), table (4) represents the means of responses for all items.

Table (4) shows how the means of all items are between 1 and 2 on a scale of 5 grades except for items $\mathrm{C} 2$ and $\mathrm{C} 3$ which slightly exceed 2 . This also shows how all participants' responses either strongly disagree or disagree on all the domain items. 
Table 4: The mean and standard deviation of domain (C): Effectiveness of the activities found in the 3rd year secondary EFL textbooks in developing oral communicative skills

\begin{tabular}{llll}
\hline No & \multicolumn{1}{c}{ Using the activities in the textbooks, students are able to: } & Mean & Std. Deviation \\
\hline C1 & speak fluently in English. (express themselves easily) & 1.4 & 0.675 \\
C2 & hold a telephone conversation in English. & 2.07 & 1.048 \\
C3 & exchange information in English. & 2.1 & 0.845 \\
C4 & express themselves in English without using Arabic. & 1.83 & 0.648 \\
C5 & speak as well as they can write. & 1.8 & 0.761 \\
C6 & answer questions based on a listening task. & 1.47 & 0.681 \\
C7 & present a summary or a comment on a topic orally. & 1.63 & 0.809 \\
C8 & make announcements in English. (e.g. school broadcasting). & 1.53 & 0.819 \\
C9 & comment on a picture, movie or a game in English. & 1.8 & 1.064 \\
C10 & debate or negotiate prices in English. & 1.8 & 0.805 \\
C11 & conduct a simple interview. & 1.47 & 0.86 \\
C12 & role-play using English. & 1.2 & 0.407 \\
\hline & Mean C & 1.675 &
\end{tabular}

The standard deviation values are less than one or around one to reflect agreement among the respondents that the activities in the target textbooks are not developing oral communicative skills. Figure 3 shows how low the activities are ranked in promoting communicative skills.

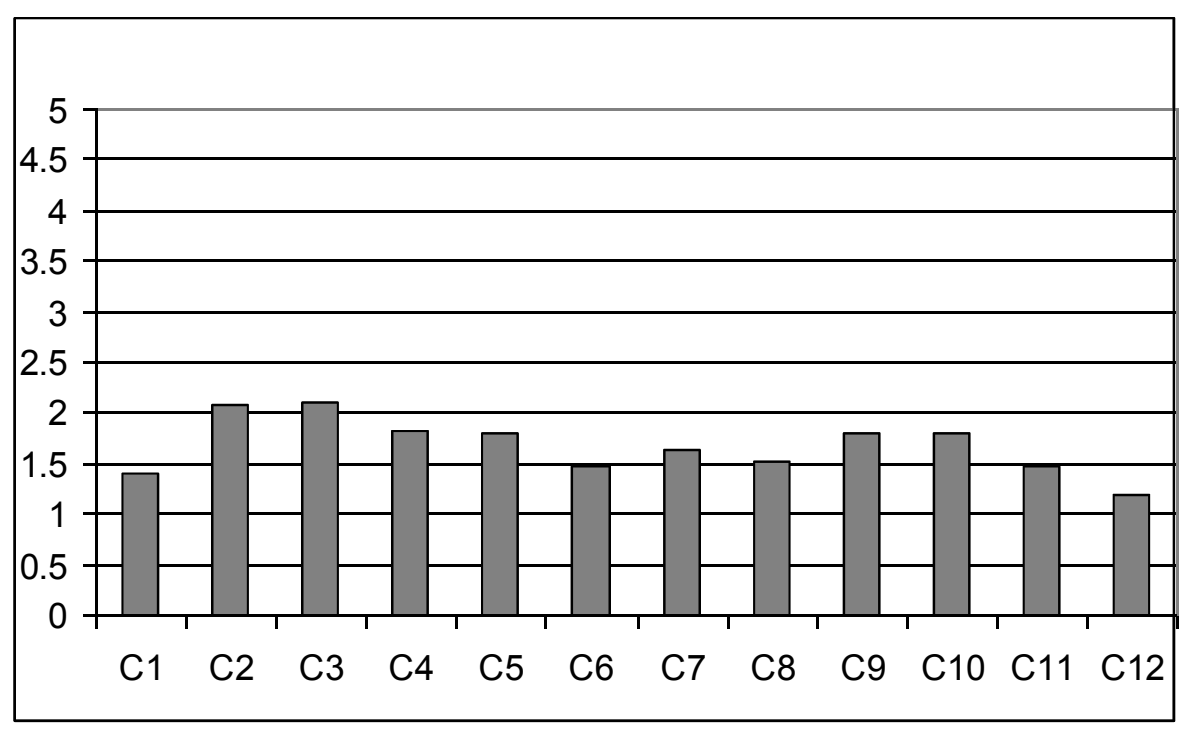

Figure 3: Means of responses for each item in domain $\mathrm{C}$

The means for responses to the 27 items of domain (D) in the questionnaire, (Types of oral communicative activities in the 3rd year secondary EFL Saudi textbooks), are shown in table 5 and figure 4. 
Table 5: The mean and standard deviation of domain (D): Types of Oral Communicative activities in the 3rd year Secondary EFL Saudi Textbooks

\begin{tabular}{|c|c|c|c|}
\hline No & $\begin{array}{l}\text { The following types of oral Communicative activities are included in } \\
\text { the textbooks: }\end{array}$ & Mean & $\begin{array}{c}\text { Std. } \\
\text { Deviation }\end{array}$ \\
\hline D1 & Organizational elements & 2.6 & 1.221 \\
\hline D2 & Content explanations & 1.4 & 0.814 \\
\hline D3 & Setting & 2.17 & 1.053 \\
\hline D4 & Dialogues/ Narrative presentations & 2.13 & 1.106 \\
\hline D5 & Dictation & 1.4 & 0.814 \\
\hline D6 & Warm up & 1.13 & 0.346 \\
\hline D7 & Role-play demonstration: & 1.5 & 0.63 \\
\hline D8 & Dialogues/ Narrative recitation: & 1.83 & 1.085 \\
\hline D9 & Reading aloud & 2.33 & 1.093 \\
\hline D10 & Question-answer-display & 1.47 & 0.629 \\
\hline D11 & Drill: repetition, substitution with little meaning attached & 1.7 & 0.952 \\
\hline D12 & Meaningful drill & 2.2 & 1.186 \\
\hline D13 & Story telling & 1.47 & 0.571 \\
\hline D14 & Information transfer: e.g. Students fill out a diagram while listening. & 1.77 & 1.104 \\
\hline D15 & Wrap-up: Students listen to a summary. & 2.1 & 1.125 \\
\hline D16 & Question-answer, referential & 1.7 & 0.915 \\
\hline D17 & Cued narratives/Dialogues & 1.43 & 0.626 \\
\hline D18 & Narration/Exposition & 1.53 & 0.571 \\
\hline D19 & Brainstorming & 1.4 & 0.563 \\
\hline $\mathrm{D} 20$ & Role-play & 1.67 & 0.661 \\
\hline D21 & Games & 1.3 & 0.466 \\
\hline D22 & Problem solving & 1.17 & 0.379 \\
\hline D23 & Drama & 1.33 & 0.479 \\
\hline D24 & Simulation & 1.27 & 0.521 \\
\hline D25 & Interview & 1.2 & 0.407 \\
\hline D26 & Discussion & 1.43 & 0.504 \\
\hline D27 & Debate & 1.27 & 0.45 \\
\hline
\end{tabular}

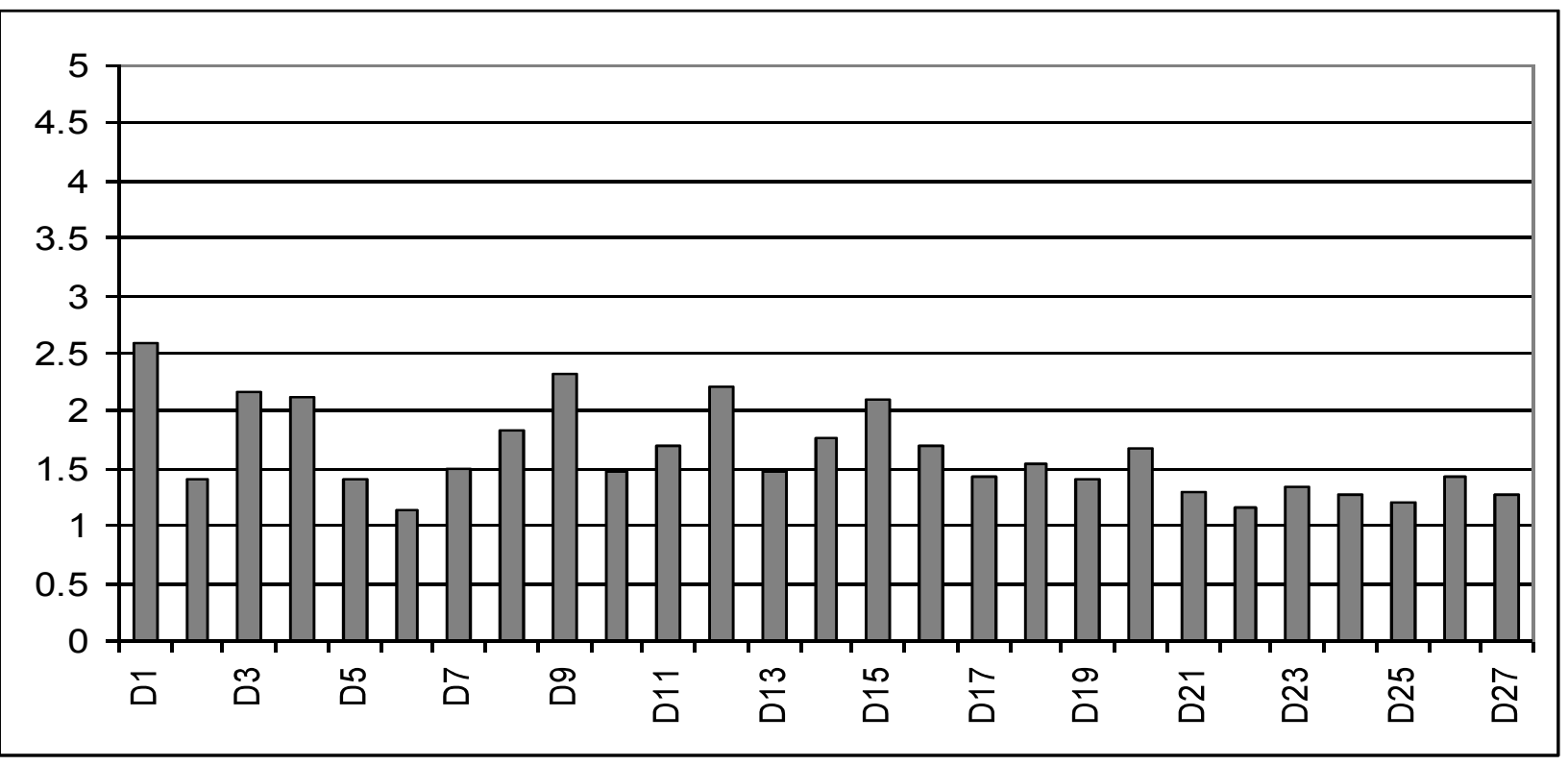

Figure 4: Means of responses for each item in domain D 
Table (5) shows how the means of all the 27 items are between 1 and 2 on a scale of 5 grades except for 6 items (D1, D3, D4, D9, D12 and D15) which were higher than 2. However, none of the item exceeded 3 degrees on the scale. This represents the participants' views on the existence of these types of oral communicative activities in the target set of textbooks. According to the means of responses, there is a severe lack of such activities in the textbooks. The standard deviation values are also less than one or around one to reflect agreement among the participants that these types of oral activities are not found in the target textbooks.

Regarding the last domain (E), (Recommendation to improve the current textbooks for the third year secondary students), the respondents suggested the following:

- Totally replacing these textbooks, which are not capable to improve the students' oral communication skills, with communicative textbooks that shed more light on listening, pronunciation and speaking activities. (Suggested by four respondents)

- modifying the current textbooks by adding communicative sections. (Five respondents)

- including listening and speaking in the monthly and final exams. (Eight respondents)

- adding supplementary communicative textbook to the current textbooks. (Six respondents)

\section{Conclusion}

The results of the preliminary study and the analysis of the survey match the results of previous studies of Rababaa (2003), Kharma et al. (1989) and Alseghayer (2007). There is a lack of oral communicative tasks and activities in the EFL textbooks that the Saudi third year secondary student faces. The rating of all activities is generally less than 40-50\%. Furthermore, the teachers, inquired about advanced oral communicative activities (free techniques), declared the absence of such activities. The results of this study assert that the textbooks require much modification or supplementary communicative materials to achieve the goals of improving the Saudi learners' oral communicative skills. 


\section{References}

Al-Seghayer, K. (2007). Impediments to teach English in the Kingdom of Saudi Arabia. MOE forum http://www.moeforum.net/vb1/showthread.php?t=87924. [3 February 2008]

Ansary, H \& Babaii, E. (2002). Universal characteristics of EFL/ESL textbooks: A step towards systematic textbook evaluation. The Internet TESL Journal, VIII(2), February 2002. http://iteslj.org/Articles/Ansary-Textbooks/. [14 May 2009].

Beale, J. (2002). Is communicative language teaching a thing of the past? Babel, 37(1), 12-16. http://www.jasonbeale.com/essaypages/clt_essay.html. [16 September 2006].

Brown, H. D. (2001). Teaching by principles: An interactive approach to language pedagogy. New York. Longman Press.

Bygate, M. (1987). Speaking. Oxford University Press. Google Books. http://books.google.com.my/books?id=XozCwaqSJFIC\&printsec=frontcover. [30 August 2007].

De Matos, F. (2000). Learning Teachers as textbook evaluators: an Interdisciplinary Checklist. IATEFL Associate BrazTESOL. Issue 157, Oct/Nov 2000, http://www.iatefl.org/content/newsletter/157.php. [22 January 2006].

Kharma, N. \& Hajjaj, A. (1989). Errors in English among Arabic speakers: analysis and remedy. England. Longman House.

Littlewood, W. (1983). Communicative language teaching: An introduction. New York. Cambridge University Press.

Murphy, J. (1991). Oral communication in TESOL: integrating speaking, listening, and pronunciation. TESOL Quarterly, 25(1).

National Center for Family Literacy and Center for Applied Linguistics. (2008). Practitioner toolkit: Working with adult English language learners. Louisville, KY, and Washington, DC: Authors.

Nunan, D. (2000). Language teaching methodology. Malaysia. Longman.

Nunan, D. (2002). Research methods in language learning. Cambridge. Cambridge University Press.

Rababah, G. (2003). Learning Communication problems facing Arab learners of English: A personal perspective TEFL Web Journal, 2 (1), 15. http://faculty.ksu.edu.sa/mdajani/Pages/ArabLearners.aspx. [12 March 2007].

Savignon, S. J. \& Wang, C. C. (2003). Communicative language teaching in EFL contexts: Learner attitudes and perceptions. IRAL, International Review of Applied Linguistics in Language Teaching, 41(3), 223 ProQuest Education Journals. 